\title{
Microbiological and Sensory Evaluation of Instant Vegetable Stock from by-Products of Frozen Food Companies Compared with the Commercial Stock Cubes in Egypt
}

\section{Emad A.H. Guirguis and Mohamed F.M. Farag}

Department of Food Hygiene, National Nutrition Institute, General Organization of Teaching Hospitals and Institutes, Egypt.

\begin{abstract}
7 he consumption of instant vegetable soup powder is increasing due to their ease of use. It was developed converting by-product frozen food, to much valuable and functional products. Five vegetable soup
\end{abstract} formulae (F1, F2, F3, F4 and F5) were created using dried vegetable waste material mixes. Microbial and sensory evaluation was conducted to select best combination of ingredients in comparison with commercial brand. The results of the microbial analysis showed that the samples had mean total aerobic viable count and molds and yeasts count ranging) from 6.0 to 9.8) $x 10^{4} \mathrm{cfu} / \mathrm{g}$ and (from 5.4 to 11$) \times 10^{2} \mathrm{cfu} / \mathrm{g}$, respectively. The coliform group (MPN) ranging from < 3.0 to 23 cell/g. Pathogens (Escherichia coli, Staphylococcus aureus, Bacillus cereus, Clostridium perfringens and Salmonella sp.) were not detected in any of the samples. The counts obtained were within the maximum acceptable levels provided by the Food and Drug Administration (FDA). Sensory evaluation on the basis of overall acceptability scores, the formula F2 is the most acceptable of all the examined samples while the commercial vegetable stock cubes comes the second, followed by formulae F3, F4, F1 and F5, respectively. Therefore, the development of innovative and safe foods has been a challenge, mainly due to lack of knowledge and technology transfer to the industry.

Keywords: by-products, vegetable stock, microbiology, sensory. 


\section{INTRODUCTION}

Waste disposal and byproduct management in food processing industry pose problems in the areas of environmental protection and sustainability. It is produced during the various steps of production, in which the desired components are extracted from the raw materials. After extraction, there are often other potentially useful components present in the remaining materials (Jayathilakan et al 2012).

In particular, the boom in health and functional foods, there is general preference for healthy soup prepared using vegetables, legumes, cereals and mushrooms. Dried instant soup has long shelf life because it is a dried food and frequent has its effective tasting time period set for a relatively long time (Jayasinghe et al., 2016).

It is well known that good quality and reasonable ratio of dehydrated soup depend on variety and functional properties of supplemented individuals (Abdel-Haleem and Omran 2014). A balance of nutrients may be obtained by including whole cereals, vegetables, pulps and milk products, etc. Such these diets supply a large proportion of our energy needed, carbohydrate, protein, dietary fiber, amino acids and minerals (Pandey et al 2006). Also, functional ingredients can be easily incorporated into soup powders to provide health benefits (Ravindran and Matia-Merino 2009).

Any dehydrated soup mix should be rehydratable and cookable within a minimum time period, and should be as nutritious and palatable as canned or frozen products. Commercially prepared soup mixes are usually made using (MSG) monosodium Glutamate to enhance desired flavor

\section{(Abeysinghe and Illeperuma 2006).}

The manufacture of dry soups typically involves dry mixing, and in many cases no 
microbiological kill step is applied in the process. Control of the factory environment involves the prevention of the moisture, through the exclusion of water from the manufacturing processes and the use of dry cleaning procedures (Fassung 2008).

Although no Egyptian standards for instant vegetable stock were edited, FDA published in 2013 microbiological reference criteria for dry mixes for soup and souces: $\mathrm{Cl}$. perfringens $10^{3}$ $\mathrm{cfu} / \mathrm{g}$, molds and yeasts count $10^{4} \mathrm{cfu} / \mathrm{g}$, coliforms $10^{3} \mathrm{cfu} / \mathrm{g}$, total aerobic viable count $10^{6}$ $\mathrm{cfu} / \mathrm{g}$ and Salmonella sp should not detected in $25 \mathrm{~g}$ ).

\section{Abeysinghe}

and

Illeperuma (2006) found that the aerobic plate count of the developed vegetable soup mix was within the safe range $\left(2.3 \times 10^{3} \mathrm{cfu} / \mathrm{g}\right)$, and they suggested that the reconstitution ratio of 1:15 produced an acceptable product.
The present study aimed to: 1) Magnify the by-products of frozen food companies by converting them to more valuable and functional products, and 2) Evaluate all obtained formulae microbiologically and sensory which represent a good indicator of keeping quality.

\section{MATERIALS \& METHODS}

\section{Materials:}

Spinach leaves, spinach roots, cabbage leaves, cauliflower leaves and peas skins were obtained by special arrangement from the United Company for food industries "Montana", Qualub, Qualubia Government, Egypt. Peas kernels, bird eye, lentil, green beans, dehydrated okra, moulokhia, potato and tomato were purchased from the local markets. Dehydrated onion, garlic and onion skins were obtained from the New Beni Sueif Company for preservation, Dehydration and Industrization of Vegetables, Beni Sueif El- 
Goudida, Nile East, Beni Sueif Government, Egypt.

Twenty random commercial vegetable stock cubes were purchased from local markets in Egypt (Al-Subhi, 2013).

\section{Methods:}

- Experimental Design:

Vegetables were prepared, i.e., sorted, washed, peeled, sliced, blanched, washed, dried, milled and sieved into powdered form according to Jayasinghe $\boldsymbol{e t}$ al (2016).

- Formulae preparation:

For the five formulae ( $\mathrm{F} 1$, F2, F3, F4 and F5) preparation, all the dehydrated food items were weighted by specific ratios such as mentioned in Table (1).

- Samples preparation:

$$
\text { Commercial vegetable }
$$
stock cubes brand product was purchased from local market in Cairo, Egypt. Twenty commercial samples and $100 \mathrm{~g}$ of each dry formulae samples were ground into powder using a food blender (Blender 8010ES, WARING commercial, USA) and transferred into polyethylene bags. The bags were stored in a desiccators containing calcium chloride to keep the samples dry (Al-Subhi, 2013). Each value represents the average of three replicates.

- Microbiological analysis:

Samples $(25$ g) in replicates were homogenized with sterile peptone water $0.1 \%$ (225 ml) using stomacher apparatus (Seward Stomacher 3500, Lab system, England), then serial dilutions in peptone water $0.1 \%$ were performed (Salari et al., 2012). For the detection and enumeration of microorganisms (total aerobic viable count, molds and yeasts count, coliforms, E. coli, Staph. aureus, B. cereus, $\mathrm{Cl}$. perfringens and Salmonella sp.), samples were subjected to standard media purchased from Oxoid and Difco and prepared following its instructions 
according to International Commission of Microbiological Specification for Food (ICMSF 1978 and 1996) and Harrigan (1998).

\section{Sensory evaluation:}

The resultant soup samples were sensory evaluated after dissolving in hot water $(10 \mathrm{~g}$ dried vegetarian soup mixtures $165 \mathrm{ml}$ water) for its sensory characteristics, i.e. aroma, taste, texture, color and overall acceptability. The evaluation was carried out by ten panelists according to the method of Wang et al. (2009). Thus, the results represent the following scores: very good, 8-9 (80-90\%); good, 6-7 (60-70\%); fair, 4-5 (40-50\%); poor, 2-3 (20-30\%) and very poor, $0-1$ (0-10\%).

\section{REDULTS \&DISCUSSION}

The data presented in Table (2) indicated the microbiological evaluation of all soup products. From such data, it could be noticed that the F 5 recorded the highest total aerobic viable count $\left(9.8 \times 10^{4}\right.$ $\mathrm{cfu} / \mathrm{g}$ ), followed by the values of F1, F4, F3, commercial brand and $\mathrm{F} 2$, i.e., $(9.0,8.5,8.0,6.2$ and 6.0) $\times 10^{4} \mathrm{cfu} / \mathrm{g}$, respectively. The same behavior was recorded for the molds and yeasts count ranging (from 5.4 to 11 ) $\times 10^{2}$ $\mathrm{cfu} / \mathrm{g}$. Regarding the coliforms bacteria (MPN), F1, F3, F4 and F5 recorded (2.03, 0.82, 1.53 and 2.3) $\times 10^{1} \quad$ cells $/ g$, respectively, while was $<3$ cells/g in F2 and the commercial brand.

These results are in agreement with the parameters mentioned by FDA (2013), which is not considered to show poor quality. This microbial content does not necessarily imply deterioration problems for the instant vegetable stock. The same results were found in dry soups by Oguntoyinbo (2012) and Al-Subhi (2013).

The coliforms contamination of F1, F3 and F5 could be attributed to the spinach roots included. Kim $\boldsymbol{e t}$ 
al. (2011) reported that, contamination risk was higher (70\%) in roots vegetables, thus indicated that the root vegetable ingredient of several food products might be an important source of contamination.

The rest of the pathogenic bacteria including E. coli, Staph. aureus, B. cereus, $\mathrm{Cl}$. perfringens and Salmonella $s p$. were not detected in all of the tested formulae.

This revealed that the different ingredients and their quantities used in formulating the soup mixture are comparable.

High number of microbial counts in dehydrated products is due to the concentration of organism on a per gram basis along with product concentration.

Clostridium perfringens is the problematic organism, but its growth in dried products is less likely due to low water activity. Th method of handling of the reconstituted soup is crucial, as Cl. perfringens can grow at temperature up to $55^{\circ} \mathrm{C}$ in reconstituted products (Abeysinghe and Illeperuma, 2006).

The presence of Staph. aureus in dried soup or bouillon products can be mainly attributed to improper GMP/GHP or contaminated ingredients used in the manufacture of the final product and the organism may be used as a hygienic indicator for these products.

There is no effective inactivation step during the blending of dry soup products. Control of B. cereus in such products is applied through effective supplier programs. While in case of molds and yeasts count, it is important to note that aflatoxins produced by moulds are frequently detected in certain dry soup ingredients and in particular in spices (Fassung, 2008).

According to Mujumdar (2014), the process of drying is not per se lethal to all microorganisms and many may 
survive. The more heat-resistant organisms are the more likely survivors (e.g., bacterial spores, yeasts, molds and thermoduric bacteria). Thus there is a strong possibility for microbial growth, including pathogens, before the $\mathrm{a}_{\mathrm{w}}$ of the product falls below the critical level for each organism.

Factors that influence markedly the microbial population of dehydrated vegetables include the microbial quality of fresh produce; the method of pretreatment of the vegetables (peeling, blanching, etc.); the time elapsed between preparation of the vegetables and start of the dehydration process; the time involved in the dehydration of the vegetables; the temperature of dehydration; the moisture content of the finished product; and the general level of sanitation in the dehydration plant. The use of appropriate processing techniques, simple cleaning and segregation procedures could help reduce levels of contamination of foods for human consumption (IAEA, 2004).

The level and nature of microorganisms found in dry soup mixes is directly impacted by the microbiological quality of the raw materials and effective supplier management is critically important (Fassung, 2008).

It is assumed that lower microbial loads would be possible in a more controlled factory environment (Swarts, 2012).

In

particular, microorganisms may come from soil during harvesting and environmental conditions contribute to the contamination of this type of foods which may partially carry their microbiological load into processed final food products. It was considered that the variety of raw materials and the diversity of processing techniques might have affected the prevalence ratios of the bacteria (Asku et al., 2016). 
Microbial quality of equipment surfaces in contact with foods is of great importance for quality food production. Occurrence of crosscontamination is possible with unclean and non-disenfected equipments and surfaces (Shaker et al., 2007).

The results of Table (3) showed that on the basis of overall acceptability sources, F2, F3 and commercial brand rated "very good" (80-87\%) while formulae F1, F4 and F5 rated "good" (71-76\%). Although, all tested products recorded very good and good rates of grade.

The highest mean score obtained for formula F2 followed by commercial brand, formulae F3, F4, F1 and F5 rated lower in aroma, taste, texture and color where overall acceptance as reflected by mean of score (percent) was 34.6 $(86.5 \%), \quad 33.5 \quad(83.8 \%), \quad 32.4$ (81\%), 29.6 (74\%), 29.3 (73.3\%) and $28.9(72.3 \%)$, respectively.

The highest scores may be due probably to the highest fat and protein compared to the other stocks. The relatively lower mean scores of the formula F5 are probably due to the fact that it is not as popular. All the stocks were still acceptable to the panelists as indicated by their mean score for overall acceptability (Al-Subhi, 2013). However, the commercial stock cubes come the second to the most acceptable of all the dry stock samples.

Dry soup should possess desired quality, representing the dominant flavor and aroma of the ingredients used. It is desirable that the product be free from off flavor, off taste, unacceptable aroma and faulty texture (AbdelHaleem and Omran, 2014).

MSG restores some of the original flavor, increases palatability and raises overall flavor level while reducing sodium chloride concentration. Onion was chosen as it is considered a flavoring agent, a condiment, and a vegetable. Tomato was used mainly to improve flavor and therefore 
was added separately from the other vegetables (Abeysinghe and Illeperuma, 2006).

The results show positive correlation of microbial growth and deterioration in sensory quality. The reduction of sensory quality may be due to the slight increase of microbial and fungal growth (Jayasinghe et al., 2016).

\section{CONCLUSION}

Dried by-products as basic ingredients in addition to flavors and additives were used successfully to produce instant vegetable soup mixes. These formulae are acceptable and safe without any resident microorganisms. The sensory scores of the soup formulae mixes were palatable and accepted.

\section{REFERENCES}

\section{Abdel-Haleem AMH and} Omran AA (2014):

Preparation of dried vegetarian soup supplemented with some legumes. Food and
Nutrition sciences, 5: 2274-2285.

Abeysinghe $\mathrm{CP}$ and Illeperuma CK (2006):

Formulation of an MSG (Monosodium Glutamate) free instant vegetable soup mix. J. Natn. Sci. Foundation Sri Lanka, 34(2): 91-95.

Aksu F, Altunatmaz SS, Issa G, Togay SÖ and Aksu H (2016):

Prevalence and identification by multiplex polymerase chain reaction patterns of Cronobacter spp. Isolated from plantbased foods. Food Sci. Technol., 36(4): 730-736.

\section{Al-Subhi FMM (2013):}

Evaluation of Mushrooms Broth Cube and Its Compared With Maggi Broth Cube Products in Saudi Arabia. J. Amer. Sci., 9(5): 250-255. 
Fassung K (2008):

Microbiological

Specifications for Dry

Soups and Bouillons, and Ingredients to be used for Dry Soups and Bouillons (2007) - New AIIBP Guidelines.

Generalsekretär, AIIBP/FAIBP,

Reuterstraße 151, D-53113

Bonn. p. 33-40.

$\begin{array}{lr}\text { Food } \quad \begin{array}{r}\text { and } \\ \text { Administration }\end{array} & \begin{array}{r}\text { Drug } \\ \text { (FDA, }\end{array} \\ \text { 2013): } & \\ \text { Revised Guidelines } & \text { for the } \\ \text { assessment } & \text { of } \\ \text { microbiological } & \text { quality of } \\ \text { processed } & \text { foods. } \\ \text { Department of } & \text { Health, } \\ \text { Food and } & \text { Drug } \\ \text { Administration, } & \text { Filinvest } \\ \text { Corporate City, } & \text { Alabang, } \\ \text { Muntinlupa City, p.11. }\end{array}$

Harrigan WF (1998):

Laboratory Methods in Food Microbiology. $3^{\text {rd }}$ ed.
Academic Press Ltd., p: 532.

IAEA (International Atomic Energy Agency, 2004) :

Radiation, people and environment. Agency Vienna, Austria, IAEA/PI/A. 75/04-0039.

ICMSF

(International

Commission

on Microbiological Specification for foods, 1978):

Microorganisms in Food 1. Their Significance and Methods of Enumeration $\left(2^{\text {nd }}\right.$ ed), Toronto, University of Toronto Press, 434 p.

ICMSF

(International

Commission on Microbiological Specification for foods, 1996):

Microorganisms in Food 5. Application of the Hazard 
Analysis Critical Control

Point (HACCP) System to

Ensure Microbiological

Safety and Quality (in

Portuguese) Livraria

Varela Ltda, Sao Paulo, $513 \mathrm{p}$.

Jayasinghe

PS,

Pahalawattaarachchi V and Ranaweera KKDS (2016):

Formulation

of nutritionally superior and low cost seaweed based soup mix powder. J. Foood Process. Technol., 7(4): 571-576.

Jayathilakan K, Sultana K, Radhakrishna $K$ and Bawa AS (2012):

Utilization of byproducts and waste materials from meat, poultry and fish processing industries: a review. J. Food Sci. Technol., 49(3): 178-293.

Kim JB, Park YB, Kang SH, Lee ML, Kim KC, Jeong
HR, Kim DH, Yoon MH, Lee JB and Oh DH (2011):

Prevalence, genetic diversity and antibiotic susceptibility of Cronobacter spp. (Enterobacter sakazakii) isolated from Sunshik, its ingredients and soil. Food Sci. Biotech., 20(4): 941948.

\section{Mujumdar AS (2014):}

Handbook of Industrial Drying. $4^{\text {th }}$ ed. CRC press, p. 632.

\section{Oguntoyinbo FA (2012):}

Development of Hazard Analysis Critical Control Points (HACCP) and Enhancement of Microbial Safety Quality during Production of Fermented Legume Based Condiments in Nigeria. NIFOJ, 30(1): 59 -66 .

\section{Pandey M, Anbidi AB, Siagh S} and Singh RP (2006) : 
Nutritional evaluation of leafy vegetable Paratha. $J$. Human Ecol., 19:155-156.

\section{Ravindran $G$ and Matia- Merino L (2009): \\ Starch-Fenugreek \\ (Trigonella \\ foenum- \\ graecum L.) Polysaccharide \\ Interactions in Pure and Soup Systems. Food Hydrocolloids, 23:1047- 1053.}

\section{Salari R, Habibi Najafi MB,} Boroushaki MT, Mortazavi SA and Fathi Najafi M (2012):

Assessment of the microbiological quality and mycotoxin contamination of Iranian red pepper spice. J. Agr. Sci. Tech., 14: 1511-1521.
Shaker R, Osaili T, Al-Omary W, Jaradat $\mathrm{Z}$ and AlZuby M (2007)

Isolation of Enterobacter sakazakii and other Enterobacter sp. From food and food production environments. Food Cont., 18(10): 1241-1245.

\section{Swarts KM (2012):}

Development of a stock cube with functional food characteristics. Cape Peninsula, Univ. of Technology. P. 76.

Wang R, Zhang M, Mujumdar AS and Sun JC (2009): Microwave freeze-drying characteristics and sensory quality of instant vegetable soup. Drying Technology, 27: 962-968. 
Table (1): Recipes for soup formulae F1, F2, F3, F4, and F5 manufactured from the by-products of frozen food companies $(\mathrm{g} / 100 \mathrm{~g})$.

\begin{tabular}{|l|c|c|c|c|c|}
\hline \multicolumn{1}{|c|}{ Components } & F1 & F2 & F3 & F4 & F5 \\
\hline $\begin{array}{c}\text { - Basic Ingredients } \\
\text { (Dehydrated) }\end{array}$ & & & & & \\
\hline Peas skin & 11.0 & 0 & 0 & 0 & $\mathbf{0}$ \\
\hline Potato skin & 9.0 & 0 & 0 & 4.8 & $\mathbf{0}$ \\
\hline Tomato skin & 12.0 & 15.0 & 8.0 & 19.1 & $\mathbf{1 2}$ \\
\hline Spinach roots & 6.0 & 0 & 4.0 & 0 & $\mathbf{7 . 0}$ \\
\hline Peas pods & 5.0 & 0 & 4.0 & 0 & $\mathbf{7 . 0}$ \\
\hline Cabbage leaves & 20.0 & 0 & 14.0 & 0 & $\mathbf{8 . 0}$ \\
\hline Cauliflower leaves & 25.0 & 23.0 & 9.0 & 15.0 & $\mathbf{4 . 0}$ \\
\hline Beard eye & 0 & 11.0 & 0 & 0 & $\mathbf{7 . 0}$ \\
\hline White bean & 0 & 9.0 & 0 & 0 & $\mathbf{5 . 0}$ \\
\hline Lentil & 0 & 19.9 & 0 & 0 & $\mathbf{1 0 . 0}$ \\
\hline Molokhia & 0 & 0 & 52.5 & 0 & $\mathbf{0}$ \\
\hline Okra & 0 & 4.5 & 0 & 50.0 & $\mathbf{0}$ \\
\hline Peas & 0 & 0 & 0 & 0 & $\mathbf{1 4 . 0}$ \\
\hline Spinach & 0 & 0 & 0 & 0 & $\mathbf{7 . 0}$ \\
\hline - Flavors (Dehydrated) & & & & & \\
\hline Onion & 4.0 & 5.0 & 0 & 3.0 & $\mathbf{3 . 0}$ \\
\hline Garlic & 1.4 & 2.0 & 3.0 & 2.0 & $\mathbf{2 . 0}$ \\
\hline Parcely & 0.5 & 0.5 & 0 & 0.5 & $\mathbf{0 . 5}$ \\
\hline Black paper & 0.4 & 0.2 & 0.3 & 0.4 & $\mathbf{0 . 3}$ \\
\hline - Additives & & & & & \\
\hline Citric acid & 0.2 & 0.2 & 0 & 0 & $\mathbf{0 . 2}$ \\
\hline Potato starch & 2.0 & 2.0 & 0 & 0 & $\mathbf{5 . 0}$ \\
\hline Yeast extract & 0.5 & 0.5 & 0 & 0 & $\mathbf{0 . 5}$ \\
\hline MSG & 0.2 & 0.2 & 0.2 & 0.2 & $\mathbf{0 . 2}$ \\
\hline Sugar & 0.3 & 0.3 & 0 & 0 & $\mathbf{0 . 5}$ \\
\hline Salt & 1.0 & 1.0 & 2.0 & 2.0 & $\mathbf{1 . 3}$ \\
\hline Onion Skin powder & 1.5 & 1.5 & 1.5 & 1.5 & $\mathbf{1 . 5}$ \\
\hline Skimmed milk & 0 & 1.2 & 0 & 0 & $\mathbf{1 . 0}$ \\
\hline Potato skin & $\mathbf{0}$ & $\mathbf{3 . 0}$ & $\mathbf{1 . 5}$ & $\mathbf{1 . 5}$ & $\mathbf{3 . 0}$ \\
\hline & & & & & \\
\hline
\end{tabular}


Microbiological and sensory evaluation of instant vegetable stock from by-products of frozen food companies compared with the commercial stock cubes in Egypt

Emad AH Guirguis and Mohamed FM Farag

Table 2: Microbiological evaluation of different soup formulae manufactured from the by-products of frozen food companies compared with commercial brand.

\begin{tabular}{|l|l|l|l|l|l|l|}
\hline \multirow{2}{*}{ Microorganisms } & \multicolumn{5}{|c|}{ Formulae } & $\begin{array}{c}\text { Commeri } \\
\text { albrand }\end{array}$ \\
\cline { 2 - 7 } & \multicolumn{1}{|c|}{ F1 } & \multicolumn{1}{|c|}{ F2 } & \multicolumn{1}{|c|}{ F3 } & \multicolumn{1}{|c|}{ F4 } & \multicolumn{1}{|c|}{5} & \\
\hline $\begin{array}{l}\text { Total } \\
\text { viable count }\end{array}$ & $9.0 \times 10^{4}$ & $6.0 \times 10^{4}$ & $8.0 \times 10^{4}$ & $8.5 \times 10^{4}$ & $9.8 \times 10^{4}$ & $\mathbf{6 . 0 \times 1 0}$ \\
\hline $\begin{array}{l}\text { Molds and } \\
\text { yeasts count }\end{array}$ & $8.9 \times 10^{2}$ & $5.4 \times 10^{2}$ & $7.7 \times 10^{2}$ & $8.3 \times 10^{2}$ & $11 \times 10^{2}$ & $\mathbf{6 . 4 \times 1 0 ^ { 2 }}$ \\
\hline Coliform group & $2.03 \times 10^{1}$ & $<3.0$ & $0.82 \times 10^{1}$ & $1.53 \times 10^{1}$ & $2.3 \times 10^{1}$ & $<3.0$ \\
\hline E. coli & ND & ND & ND & ND & ND & ND \\
\hline Staph. aureus & ND & ND & ND & ND & ND & ND \\
\hline B. cereus & ND & ND & ND & ND & ND & ND \\
\hline Cl. perfringens & ND & ND & ND & ND & ND & ND \\
\hline Salmonella sp & ND & ND & ND & ND & ND & ND \\
\hline
\end{tabular}

Table 3: Sensory evaluation of different soup formulae manufactured from the by-products of frozen food companies compared with commercial brand.

\begin{tabular}{|l|c|c|c|c|c|c|}
\hline \multirow{2}{*}{ Attribute } & \multicolumn{5}{|c|}{ Formulae } & $\begin{array}{c}\text { Commer } \\
\text { cial } \\
\text { brand }\end{array}$ \\
\cline { 2 - 7 } & F1 & F2 & F3 & F4 & F5 & $\mathbf{8 . 1}$ \\
\hline Aroma & 7.5 & 8.2 & 8.0 & 7.1 & 7.3 & $\mathbf{8 . 4}$ \\
\hline Taste & 7.5 & 8.5 & 8.2 & 7.6 & 7.4 & $\mathbf{8 . 7}$ \\
\hline Texture & 7.1 & 9.1 & 8.0 & 7.4 & 7.0 & $\mathbf{8 . 3}$ \\
\hline Color & 7.2 & 8.8 & 8.2 & 7.5 & 7.2 & $\mathbf{3 3 . 5}$ \\
\hline $\begin{array}{l}\text { Overall } \\
\text { acceptability } \\
(\%)\end{array}$ & $\begin{array}{c}\mathbf{2 9 . 3} \\
(\mathbf{7 3 . 3 \% )}\end{array}$ & $\begin{array}{c}\mathbf{3 4 . 6} \\
(\mathbf{8 6 . 5 \% )}\end{array}$ & $\begin{array}{c}\mathbf{3 2 . 4} \\
(\mathbf{8 1 \% )}\end{array}$ & $\begin{array}{c}\mathbf{2 9 . 6} \\
\mathbf{( 7 4 \% )}\end{array}$ & $\begin{array}{c}\mathbf{2 8 . 9} \\
\mathbf{( 7 2 . 3 \% )}\end{array}$ & $\mathbf{( 8 3 . 8 \% )}$ \\
\hline
\end{tabular}




\section{التقييم الميكروبى والحسى لمساحيق شوربة الخضار المصنعه من التواتج الثانويه لمصانع تجميد الأغذيه ومقارنتها بمكعبات الشوربه المتداوله بالأسواق المصريه}

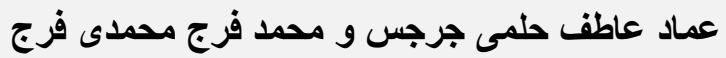

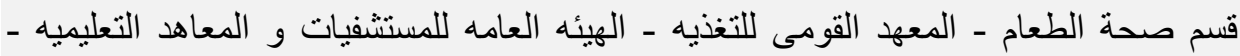

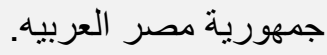
الملخص العربي التهني

يتزايد بإستمر ار إستهلاك شوربة الخضروات سريعة الذوبان نظر السهولة وسر عة التهات

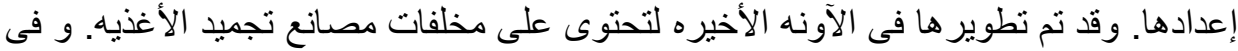

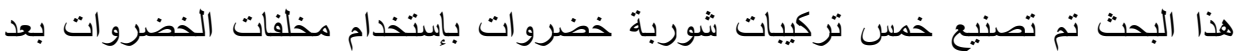

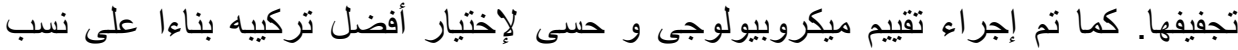

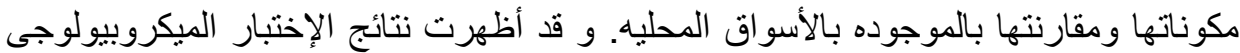

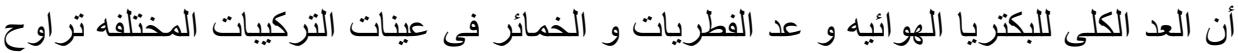

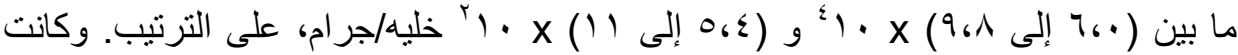

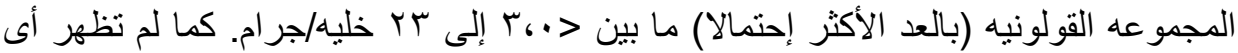

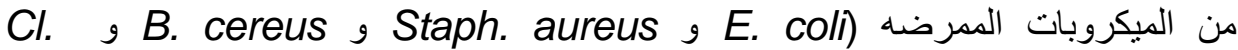
) فى أيا من عينات الدراسه. كما كانت الأعداد فى و (Salmonella sp. perfringens

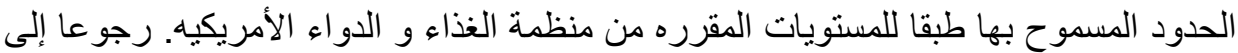

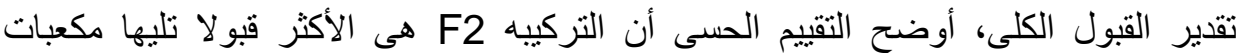

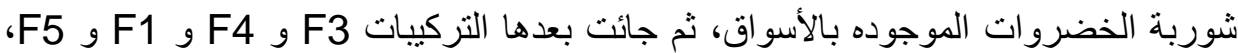
على الترتيب. لذللك فإن تطوير هذا النوع من الأغذيه الجديده بطريقه آمنه يعتبر تحديا، نظر الترات لغياب المعرفه و التقنيات المستخدمه في التصنيع.

الكلمات الداله: مخلفات الأغذيه - شوربة الخضروات ـ ميكروبيولوجى - إختبار ات حسيه. 